\begin{tabular}{l} 
MISCELLANEA \\
GEOGRAPHICA \\
\hline
\end{tabular}

Vol. 13/2008

pp. $163-168$

\author{
Tomasz Grabowski \\ University of Warsaw - Faculty of Geography and Regional Studies - Department of Geoecology \\ 00-927 Warsaw, Krakowskie Przedmieście 30 \\ e-mail: grabiec@uw.edu.pl
}

\title{
WILL XEROTHERMIC GRASSLANDS OF THE PONIDZIE REGION SURVIVE?
}

\begin{abstract}
Xerothermic grasslands are veritable botanical gems of the Ponidzie region, located in the upland zone of Poland. Most of these exceptional plant communities have been formed as a result of deforestation, in habitats characterized by specific climatic, hydrological and soil conditions. The result of the natural reserve protection of the xerothermic grassland, however, is opposite to the desired result. The survival of the xerothermic grassland depends on the change in the approach to their protection. Xerothermic grasslands are an excellent example of the difficulties with maintaining very valuable, but semi-natural and anthropogenic communities, related to a large extent to traditional, extensive forms of agriculture. Similar problems occur in the case of gladiolus meadows in lower subalpine forest zones or of once-mown molinion meadows in river valleys.
\end{abstract}

Key words: xerothermic grass, natural reserve protection, substitute communities, cultural landscape

"Xerothermic grasses" is the term used in Poland to denote grass communities resembling natural steppe formations in southeastern Europe. From the phytosociological point of view, xerothermic grasses belong to the Festuco-Brometa class, that is, to continental steppe grasses. The class is divided into three basic alliances (Matuszkiewicz 2001): rupicolous grasses Seslerio-Festucion, meadow-steppe Cirsio-Brachypodion and very xerophilous steppe Festuco-Stipion. In Central-Western Europe, the class Festuco-Brometa is represented by the order Brometalia, that is, dry and semi-dry submediterranean xerothermic grasslands similar to the steppe communities of the Mediterranean region (Fukarek 1967). 
In natural conditions the steppe formations Festucetalia are related to the moderate, continental climate in its semi-dry variety, with a decisive domination of potential evaporation over precipitation. In the soil, during the vegetation period, percolation is equivalent or smaller than infiltration. In this situation, calcium compounds do not undergo leaching. The dominance of the $\mathrm{Ca}^{2+}$ cation in the sorption complex becomes the geochemical characteristic of the soils. As a result, zonal soils (black earths and chestnut soils) with weakly alkaline or neutral $\mathrm{pH}$ dominate in areas with natural xerothermic grasses.

In Central Europe (Poland, Germany) the climate is definitely more humid. Potential evaporation is equal to $100-110 \%$ of precipitation, while the actual evaporation, about $60-80 \%$ of precipitation. The dominating processes in the soils are those of percolation that cause leaching of calcium compounds and their washing down into the soil profile. As a result, soils become gradually acidified. Soils with weakly alkaline or neutral $\mathrm{pH}$ are formed in Poland only on the bedrock rich in calcium compounds, such as limestone, marl, dolomite, gypsum, loess, carbonate clays and morainic sands.

In Central Europe, only few xerothermic grasslands can be regarded as natural communities. Such exceptional grasses are either rupicolous grasses Seslerio-Festucion or xerophilous steppe grasses Festuco-Stipion. They are usually climatic relics of the early Holocene. Much more frequently, xerothermic grasses in Poland are substitute communities occurring in place of forest and scrub communities. They occur as a result of the coincidence of several natural and industrial factors, such as:

- Relief

- Large inclination - fast water drainage through surface run-off.

- Heat exposure - absorption of the increased dose of solar radiation.

- Geological structure

- Dry, rocky substratum - strong heat contrasts of soil and of the near-surface air layer.

- Rocky, fissured substratum - fast water drainage through surface run-off and percolation.

- Silty rock-waste - fast water drainage through evaporation.

- Soil chemistry

- Weakly alkaline $\mathrm{pH}$, domination of the $\mathrm{Ca}^{2+}$ cation in the sorption complex - imitation of chemical conditions of soils under natural grassland. 
- Human activity

- Grazing, mowing - prevention of natural succession and stabilization of grassland vegetation.

The Pinczów region is located in the upland belt (Fig. 1). After World War II, eight natural reserves for protection of xerothermic grasses were created: Skowronno Dolne, Polichno, Krzyżanowice, Skotniki Górne, Skorocice, Winiary Zagojskie, Przęślin, Góry Wschodnie. Their common characteristic is calcareous bedrock (mainly gypsum, less frequently limestone and marl) and the localization on the top of hills or on slopes with warm exposure. The history of most of them was the following:

1. Forest, in form of oak-hornbeam forest (Tilio-Carpinetum) or thermophilous oak forest (Potentillo albae-Quarcetum) (a few centuries ago).

2. Introduction of pig, goat, horse, cattle, sheep grazing to the forest. The creation of a "forest pasture".

3. Deforestation.

4. Gradual domination of xerothermic plants in the pasture.

5. Final formation of xerothermic grassland functioning as extensive pasture.

6. The discovery by botanicians of the exceptional character of xerothermic grasslands (the period between the two world wars).

7. Protection of the most beautiful xerothermic grassland by creating natural reserves (after WWII) .

8. Appearance of the problem of overgrowing of the protected grasslands (turn of the $21^{\text {st }}$ century).

9. „Strengthening” of the protection of xerothermic grassland through their placement on the list of the European Ecological Network Natura 2000 (code 6210).

The greatest problem related to the maintaining of xerothermic grassland is the encroaching of tall perennial plants, shrubs and trees, that is, the plant succession, which should end with a forest community of the Tilio-Carpinetum or Potentillo albae-Quarcetum type. The surfaces of xerothermic grassland used to be private property. Xerothermic grasslands functioned as extensive pastures or wasteland occasionally used for grazing. As part of noble actions aiming at more effective protection of botanical gems of the Ponidzie region, the grass terrains have been partly bought out and transformed into natural reserves. Today, the property structure of the xerothermic grassland is as follows: 


\begin{tabular}{|c|c|c|}
\hline Natural reserve name & Type of reserve & Type of property \\
\hline Góry Wschodnie & Floral & State Treasury \\
\hline Krzyżanowice & Floral and entomological & State Treasury \\
\hline Polichno & Floral & $\begin{array}{c}\text { State Treasury, under the management } \\
\text { of the Forest District Office in Pińczów }\end{array}$ \\
\hline Przęślin & Floral & State Treasury \\
\hline Skorocice & $\begin{array}{c}\text { Inanimate nature } \\
\text { and floral }\end{array}$ & $\begin{array}{c}\text { State Treasury, under the manage- } \\
\text { ment of the Township Office in Wiślica }\end{array}$ \\
\hline Skotniki Górne & Floral & State Treasury/private \\
\hline Skowronno & Floral & Polish Academy of Sciences, Kraków \\
\hline Winiary Zagojskie & Floral & State Treasury \\
\hline
\end{tabular}

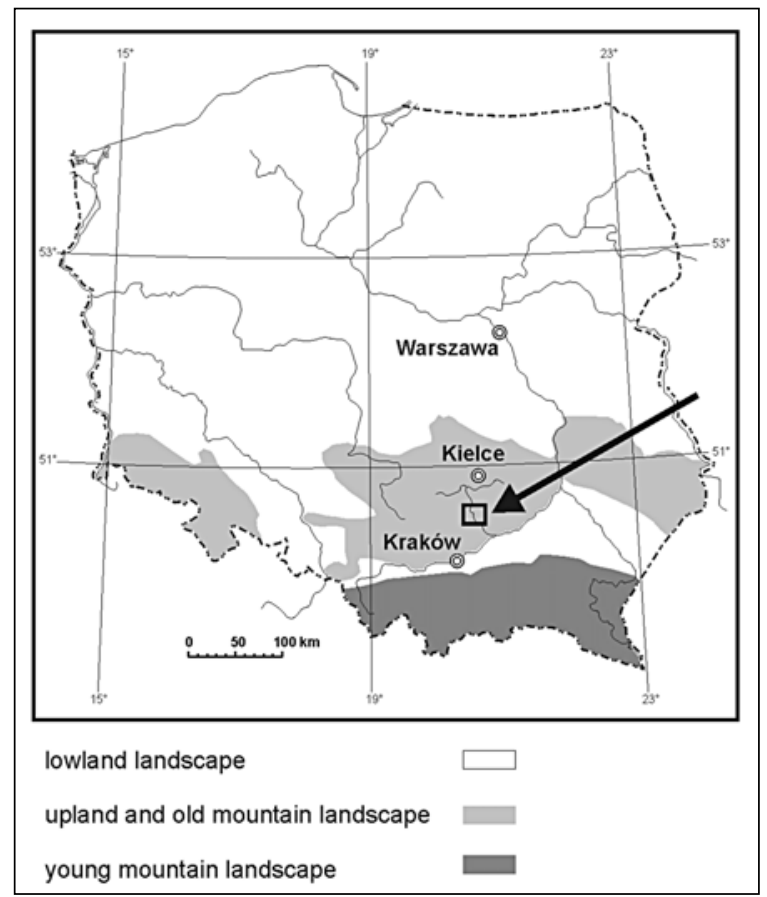

Fig. 1. The investigation area

Establishing a nature reserve makes it necessary to legalize all measures of active protection: e.g., mowing, tree and shrub cutting or else grazing. Prior to the realization of active protection, a Plan of Natural reserve Protection has to be made. This is usually delegated to a scientific team chosen by tender. Thus, the costs of active protection 
are related not only to the costs of repeatedly performed measures in the reserve, but also with the costs of creation of detailed Protection Plans. For financial reasons, a Protection Plan has been created in only one of the eight reserves discussed here. For this reason, only in one reserve, active protection measures, legalized and planned in a detailed way, are performed each year (mowing and cutting shrubs). In the remaining reserves such actions are not performed or are performed occasionally, when the regional Nature Conservation Officer issues a one-time permit.

A paradoxical cause-result circle has been thus created. Actions aiming at full protection of a natural object cause problems that threaten its survival. This remark refers to a peculiar group of natural objects. Their creation and existence are due to constant human interferenceintervention, usually related to the traditional forms of agriculture. The birth of a reserve can herald the end of this particular feature of the natural object that was to be protected. Legal changes and prohibitions cause the abolishing of elements of „traditional” extensive agriculture: grazing and mowing. In the past, over several hundred years, they were natural and cost-effective, for the local population, forms of cultivation of rocky terrains. Nowadays, measures, which used to be an element of everyday life, have to be legalized and financed.

Xerothermic grassland is a textbook example of the problem of maintaining a cultural landscape. Similar problems occur with gladiolus meadows in lower parts of subalpine forests and with once-mown molinion meadows in river valleys. Humans, managing the natural environment and the natural environment, transformed by the humans, are two basic elements of a cultural landscape. Managing a natural environment is related to the traditional way of life, to the tools, customs, costume, language, etc. Neglecting the importance of the traditional management and reducing the protection of xerothermic grassland to the protection of the natural object lead to unpredictable consequences. We have to find a substitute form of management that would halt plant succession. People who mow the grass regularly are being hired. Teams of young ecologists organize actions of goat grazing; goats are excellent in destruction of ,superfluous" shrubs and trees (Perzanowska, Kujawa-Pawlaczyk 2004).

Such activities can be compared to hypothetical actions of nature conservancy societies, consisting in „normal” agricultural measures related to cereal cultivation, organized on fields abandoned by farm- 
ers. But the aim of such actions is to protect weed communities, not to protect traditional cultures. Another comparison is to a hypothetical scattering by ecologists of $\mathrm{Ca}$ and $\mathrm{Pb}$ compounds on the terrains of old foundries to save specific communities that tolerate higher heavy metal content.

A very important problem can be seen in such actions: the problem of philosophy of cultural landscape protection. We do not know where the borderline lies between, on the one hand, noble and reasonable activities aiming at saving a natural world heading to extinction and, on the other hand, equally noble, but not entirely reasonable activities aiming at halting natural processes in nature.

\section{REFERENCES}

Fukarek F., 1967, Fitosocjologia [Phytosociology; in Polish], PWRiL, Warszawa. Matuszkiewicz W., 2001, Przewodnik do oznaczania zbiorowisk roślinnych Polski [Guide to Plant Communities in Poland; in Polish], Wyd. Nauk. PWN, Warszawa.

Perzanowska J., Kujawa-Pawlaczyk J., 2004, Poradniki ochrony siedlisk $i$ gatunków Natura 2000 - podręcznik metodyczny, tom 3: Murawy, taki, ziołorośla, wrzosowiska, zarośla [Guides to Habitat and Species Protection Natura 2000 - Methodological Textbook, Vol. 3: Grasslands, Meadows, Heathlands, Shrubs, Brushwoods; in Polish], Ministerstwo Środowiska, Warszawa.

Plan ochrony rezerwatu przyrody „Polana Polichno” na okres 1.I.2002 do 31.XII.2012, 2001, Biuro Urządzania Lasu i Geodezji Leśnej Oddział w Radomiu. [Plan of the Natural Reserve Protection "Polana Polichno" for 2002-2012; in Polish]

English translation: Małgorzata Mikulska 